\title{
THE EFFECT OF FARMING SYSTEM TYPE ON PIGLET PRODUCTION
}

\author{
Kamila Pokorná ${ }^{1}$, Jaroslav Č́tek ${ }^{1}$, Kateřina Zadinová1, Monika Okrouhlá ${ }^{1}$ \\ Nicole Lebedová2, Roman Stupka ${ }^{1}$ \\ ${ }^{1}$ Department of Animal Science, Faculty of Agrobiology, Food and Natural Resources, Czech University of Life \\ Sciences Prague, Kamýcká 129, 16500 Prague 6, Czech Republic \\ ${ }^{2}$ Department of Cattle Breeding, Institute of Animal Science, Přátelství 815, 10400 Prague - Uhříněves, Czech \\ Republic
}

Link to this article: https://doi.org/10.11118/actaun202068030567

Received: 19. 2. 2020, Accepted: 29. 4. 2020

To cite this article: POKORNÁ KAMILA, ČÍTEKJAROSLAV, ZADINOVÁ KATEŘINA, OKROUHLÁ MONIKA, LEBEDOVÁ NICOLE, STUPKA ROMAN. 2020. The Effect of Farming System Type on Piglet Production. Acta Universitatis Agriculturae et Silviculturae Mendelianae Brunensis, 68(3): 567-572.

\begin{abstract}
Reproductive performance of sows is the main factor influencing the profitability of piglet production, and simultaneously it is a basic indicator of farm management quality. The aim of this study was to compare reproductive performance of sows from intensive and extensive feeder pig operations and the costs on those farms. Evaluated were 42 sows from extensive pig farming and 464 sows from intensive pig farming. Lifelong performance was determined for all sows. The study's results show that sows from intensive pig farming achieved a mean 2.04 fewer lactations per lifetime and were culled earlier ( $\mathrm{P}<0.0001$ ). The mean total number of live-born piglets was $11.59 \%$ lower among sows from intensive pig farming, but these sows achieved 23.35\% $(\mathrm{P}<0.0001)$ higher mean number of piglets per litter. Despite shorter mean productive life, sows from intensive pig farming were more profitable. Maximizing the reproductive potential of sows has positive effect on farm profitability, and simultaneously it has no negative effect on sows' reproductive performance.
\end{abstract}

Keywords: profitability, reproduction, herd, sow, litter size, intensive farming, extensive farming

\section{INTRODUCTION}

Reproductive performance of sows is one of the most important factors influencing the profitability of feeder pig production. Number of piglets per sow per year is a basic indicator determining the quality of farm management. Many factors - both external and internal - influence reproductive performance of sows, and, at the same time, farm profitability. Among these factors, for example, is age at first insemination. Very early insemination of gilts influences their lifelong performance (Babicz et al., 2011). Recommendations for first insemination include that gilts should be inseminated for the first time at age 221-240 days (Babot et al., 2003), if their weight is $135-150 \mathrm{~kg}$ (Williamse et al., 2005), and when backfat thickness reaches $18-23 \mathrm{~mm}$
(Roongsitthichai and Tummaruk, 2014). Gilts' age at first insemination greatly influences farm profitability (Babot et al., 2003). That impact may be especially important in the case of intensive feeder pig farming, where the very continuing existence of the farming operation may depend crucially on sufficient profitability. Age at first insemination affects especially the number of live-born piglets per first litter (Babicz et al., 2011). As reported by Brzobohatý et al. (2015), a higher number of liveborn piglets per first litter was achieved by sows inseminated at age 220-240 days and the number of live-born piglets also rose when the animals' backfat thickness was increasing at the same time. This information is very important for farmers seeking to maximize their sows' reproductive potential and 
the profitability of their farms. Inseminating gilts at the wrong age will have negative effects on the animals' lifelong reproductive performance, and this has negative impacts on farm profitability (Szulc et al., 2011).

It has been confirmed that sows have higher numbers of live-born piglets in their second litters (Beyga and Rekiel, 2010), and this number continues increasing until the fourth litter (Wähner, 2009). In the case of intensive pig farming, sows are most often culled after the third farrowing and sows are regarded as being at the top of their reproductive performance at the time of the third litter (Szulc et al., 2011). Fifth and later litters typically have lower numbers of live-born piglets and unbalanced litters (Knecht and Duzinski, 2014), which characteristics are accompanied by lower profits and higher costs for measures to increase piglets' survival. It has been confirmed that piglet survival is lower in unbalanced litters. Piglets from sows in their sixth and later litters have the smallest probabilities of survival (Milligan et al., 2002). An important rule for farmers is that no more than $20-25 \%$ of the total number of litters should be from sixth and later farrowings (Hellbrügge et al., 2008).

Birth weight is an important factor influencing reproductive performance of sows and farm profitability. Piglet birth weight is influenced primarily by number of piglets per litter (Nogaj et al., 2006). Škorput et al. (2018) observed that in large litters produced by prolific sows the variability of birth weight among the piglets increases together with the number of lighter piglets. This poses a substantial challenge for farmers. According to Nevrkla et al. (2017), pigs with higher birth weight reach slaughter weight earlier. That means it is economically more beneficial to have balanced litters with good birth weights. If a litter includes more than 13 piglets, piglet weights are lower and smaller piglets do not survive. This is primarily a problem in intensive pig farming.

The number of piglets per litter is one of multiple factors influencing sow longevity and recovering the costs for their rearing. Among the others are age at first farrowing, size of first litter, number of stillborn piglets per first litter, and backfat thickness. It has been reported that sows from extensive pig farming operations are culled later from the breeding herd because the animals receive more individual care from farmers and a longer period is required to recover their costs of rearing and maintenance (Hoge and Bates, 2011). Based on the literature, it was hypothesized that sows from intensive pig farming would result in earlier cost recovery than would sows from extensive pig farming and that they would be culled earlier from the breeding herd. The aim of this study was to compare reproductive performance of sows from intensive and extensive feeder pig operations and to model the costs of these farms.

\section{MATERIALS AND METHODS}

Evaluated were 506 sows from two different types of pig farming operations. The first type was extensive, and 42 sows were evaluated from that group on a single farm. This farm keeps an open herd. The second type of pig farming was intensive, and 464 sows evaluated from that group on another single farm. This farm keeps a closed herd. All evaluated sows were Czech Landrace $\times$ Czech Large White hybrids. Sows from both farms were fed a complete compound feed twice daily. So that their lifelong performance would be known, sows were selected based on their dates of culling from the farm. Only sows having had at least one litter were included. Information about reproductive cycles of sows was recorded in the farm system. The study also examined information about every insemination, farrowing, number of live-born piglets, number of stillborn piglets, and number of weaned piglets. Piglets were weaned at 28 days of age on both farms. Economic indicators for both farms were evaluated. Other indicators (purchase prices for gilts, costs per sow per year) were taken over from current costs as reported by the Costs of Agricultural Products database at the Czech Republic's Institute of Agricultural Economics and information (IAEI, 2018). The evaluation of economic indicators served only to model the influence of farm type on profitability. Cost assumptions were taken from the database.

Statistical evaluation was performed using SAS statistical software (Statistical Analysis System, version 9.4, 2012, SAS Institute, Cary, NC, USA). A generalized linear model procedure was used to evaluate the influence of individual effects for type of pig farming's effects on age at culling, total number of live-born piglets, age at first insemination, and number of live-born piglets per litter).

To evaluate these indicators, their values were calculated and evaluated as least squares means. Also calculated were standard errors of the mean (SEM), and P-values indicating statistical significance at level $\alpha=0.05$.

\section{RESULTS}

Tab. I shows reproductive performance of sows from the first to third litters. Sows from extensive pig farming achieved 29.57\% lower mean number of live-born piglets per first litter $(\mathrm{P}<0.0001)$ and $16.12 \%(\mathrm{P}<0.0001)$ fewer weaned piglets. Sows from extensive pig farming had $80.23 \%(\mathrm{P}<0.0001)$ higher mean number of stillborn piglets per first litter. The first weaning to estrus interval was 5.15 days $(\mathrm{P}<0.0001)$ longer for sows from extensive pig farming. It is apparent from Tab. I that reproductive performance at the second litter was similar to reproductive performance at the first litter. Sows from intensive pig farming achieved 
24.54\% ( $\mathrm{P}<0.0001$ ) higher mean number of liveborn piglets and weaned $9.32 \%$ more piglets. Sows from extensive pig farming had $75.26 \%(\mathrm{P}<0.0001)$ higher mean number of stillborn piglets. The second weaning to estrus interval was 1.55 days longer for sows from extensive pig farming. At the third litter, sows from intensive pig farming achieved 20.89\% ( $\mathrm{P}<0.0001$ ) higher mean number of liveborn piglets and weaned 13.58\% ( $<$ < 0.0001) more piglets. The mean number of stillborn piglets at the third litter was 68.7\% ( $<$ < 0.0001) higher for sows from extensive pig farming. The third weaning to estrus interval was 4.54 days longer for sows from extensive pig farming. These results show that the extensive farming operation produced litters with more variable number of piglets. Under intensive farming, by comparison, stricter selection and earlier culling of sows from the farm ensure that sows produce more balanced litters.

Tab. II shows the lifelong reproductive performance of sows from the two types of feeder pig operations. Sows from both farms were inseminated for the first time at approximately the same age. Sows from extensive pig farming were inseminated at mean 2.63 days later. These sows achieved $2.04(\mathrm{P}<0.0001)$ higher number of lactations and they were culled later from the breeding herd. Sows from extensive pig farming reached an 11.59\% ( $\mathrm{P}<0.0001)$ higher mean number of total live-born piglets. They produced higher numbers of piglets from their mean 6.29 lactations. Although sows from intensive pig

I: Reproductive performance of sows from first to third litters

\begin{tabular}{|c|c|c|c|c|c|}
\hline \multirow[b]{2}{*}{ Item } & \multicolumn{2}{|c|}{ Extensive pig farming } & \multicolumn{2}{|c|}{ Intensive pig farming } & \multirow[b]{2}{*}{ P-value } \\
\hline & Mean & SEM & Mean & SEM & \\
\hline Number of sows (n) & \multicolumn{2}{|c|}{42} & \multicolumn{2}{|c|}{464} & \\
\hline \multicolumn{6}{|c|}{ Reproductive performance at first litter } \\
\hline Live-born piglets (n) & 10.24 & 0.45 & 14.54 & 0.13 & $<0.0001$ \\
\hline Stillborn piglets (n) & 0.86 & 0.16 & 0.17 & 0.02 & $<0.0001$ \\
\hline Weaned piglets (n) & 10.67 & 0.24 & 12.72 & 0.10 & $<0.0001$ \\
\hline Weaning to estrus interval (days) & 11.35 & 2.82 & 6.20 & 0.25 & $<0.0001$ \\
\hline \multicolumn{6}{|c|}{ Reproductive performance at second litter } \\
\hline Number of sows & \multicolumn{2}{|c|}{34} & \multicolumn{2}{|c|}{378} & \\
\hline Live-born piglets (n) & 12.18 & 0.52 & 16.14 & 0.17 & $<0.0001$ \\
\hline Stillborn piglets (n) & 0.97 & 0.25 & 0.24 & 0.05 & $<0.0001$ \\
\hline Weaned piglets (n) & 11.00 & 0.31 & 12.13 & 0.14 & 0.0209 \\
\hline Weaning to estrus interval (days) & 7.25 & 1.58 & 5.70 & 0.44 & 0.3085 \\
\hline \multicolumn{6}{|c|}{ Reproductive performance at third litter } \\
\hline Number of sows (n) & \multicolumn{2}{|c|}{33} & \multicolumn{2}{|c|}{337} & \\
\hline Live-born piglets (n) & 13.33 & 0.63 & 16.85 & 0.19 & $<0.0001$ \\
\hline Stillborn piglets (n) & 1.15 & 0.18 & 0.36 & 0.06 & $<0.0001$ \\
\hline Weaned piglets (n) & 10.82 & 0.37 & 12.52 & 0.09 & $<0.0001$ \\
\hline Weaning to estrus interval (days) & 9.00 & 2.41 & 4.46 & 0.51 & 0.0105 \\
\hline
\end{tabular}

SEM - standard error of the mean

II: Lifelong reproductive performance of sows from two different types of pig farming

\begin{tabular}{|c|c|c|c|c|c|}
\hline \multirow[b]{2}{*}{ Item } & \multicolumn{2}{|c|}{ Extensive farming } & \multicolumn{2}{|c|}{ Intensive farming } & \multirow[b]{2}{*}{ P-value } \\
\hline & Mean & SEM & Mean & SEM & \\
\hline Sows (n) & \multicolumn{2}{|c|}{42} & \multicolumn{2}{|c|}{464} & \\
\hline Age at first insemination (days) & 233.76 & 6.44 & 231.13 & 0.64 & 0.3606 \\
\hline Lactation (n) & 6.29 & 0.55 & 4.25 & 0.10 & $<0.0001$ \\
\hline Live-born piglets total (n) & 77.24 & 7.04 & 68.29 & 1.78 & 0.1543 \\
\hline Live-born piglets per litter (n) & 11.95 & 0.34 & 15.59 & 0.11 & $<0.0001$ \\
\hline
\end{tabular}

SEM - standard error of the mean. 
III: Profitability of two different types of pig farming

\begin{tabular}{lccc}
\hline \multicolumn{1}{c}{ Item } & Extensive farming & Intensive farming & Dif. \\
\hline Purchase of gilt (CZK) & 8,000 & Mean & 0 \\
Costs of sow per year (CZK) & 30,000 & 8,000 & 0 \\
Litters (n) & 6.29 & 30,000 & -2.04 \\
Turnover rate (litters/year) & 2.39 & 4.25 & 0.06 \\
Years in production (n) & 2.62 & 2.46 & -0.89 \\
Lifetime costs of sow (CZK) & 78,685 & 1.73 & $-26,828$ \\
Costs total (CZK) & 86,685 & 51,857 & $-26,828$ \\
Piglets per sow per year (n) & 28.58 & 59,857 & 10.37 \\
Live-born piglets total (n) & 77.24 & 38.95 & -8.95 \\
Revenue from pig sales (CZK) & 77,240 & 68.29 & $-8,950$ \\
Profit total (CZK) & $-9,445$ & 68,290 & 17,878 \\
\hline
\end{tabular}

Dif. = difference

farming produced $11.59 \%$ fewer piglets, they did so in a substantially shorter time (4.25 lactations) and simultaneously had 23.35\% $(\mathrm{P}<0.0001)$ higher mean number of piglets per litter.

Tab. III shows economic measures and profitability for the two different types of pig farming. The purchase price for a gilt was assumed to be 8,000 CZK (IAEI, 2018), and this was the same for both groups. The mean costs per sow per year were calculated at 30,000 CZK (IAEI, 2018), and this also was the same for both groups. The numbers of lifetime litters per sow were different, as sows from extensive pig farming achieved 2.04 (32.43\%) more lactations. Turnover rate differed by 0.07 , with sows from extensive pig farming achieving a mean 2.39 litters per year and those from intensive pig farming 2.46 litters per sow per year. Sows from extensive pig farming had mean production life longer by 0.89 year. They remained a mean 2.62 years on the farm and represented lifetime costs of 78,685 CZK per sow. The mean productive life of sows from intensive pig farming was a shorter 1.73 years, and lifetime costs per sow were 51,857 CZK. Total costs here refer to lifetime costs attributable to the sow plus the gilt purchase price. For sows from extensive pig farming, these costs were a mean 86.685 CZK. That was 26,828 CZK more than for sows from intensive pig farming. Sows from extensive pig farming achieved 8.95 more total live-born piglets, which is $11.59 \%$ higher. This higher number of live-born piglets resulted in higher revenues from feeder pig sales. Feeder pigs after weaning were sold for 1,000 CZK. It was assumed that mean piglet weight at weaning was $8 \mathrm{~kg}$ and so the price per kilogram was 125 CZK (IAEI, 2018). Sows from extensive pig farming achieved 77,240 CZK in revenues from piglet sales, which was 8,950 CZK more per animal. Total profit, however, which means revenues from feeder pig sales minus total costs, was higher for sows from intensive pig farming. This profit was 8,433 CZK for every sow from intensive pig farming. By contrast, every sow from extensive pig farming brought a loss of $-9,445$ CZK.

\section{DISCUSSION}

Reproductive performance of sows is very important for the economics of feeder pig production (Aasmundstad et al., 2014). Important targets for every producer are to minimize the unproductive days of sows and to maximize profit (Madej et al., 2016). Sows that are culled earlier from the breeding herd have approximately 2.4 times higher litters than do sows that are culled later (Engblom et al., 2009). The results of the present study accord with that earlier finding. Sows from intensive pig farming produced higher mean number of piglets per litter, and these sows were culled from the herd earlier than were sows from extensive farming. This could reflect the high reproductive potential of sows, due to which they are able to recover their own costs in less time. On the other hand, early culling of sows from the herd could be related to the high proportion of sows in their first litters, which can be hazardous to those animals. Already at first litter sows from the intensive farming operation had a high number of piglets, and this could be problem for subsequent reproductive performance and the sows' future profitability (Soede et al., 2013). This was not confirmed by our results to be the case, however. A suitably chosen system for culling sows from the breeding herd causes balanced production (Beek et al., 2014). In the present study it was observed that in extensive pig farming balanced production is ensured by retaining prolific sows in the breeding herd for a longer time. Sows from extensive pig 
farming reached a mean 6.29 lactations per sow. In some unique cases, sows from extensive farming achieved as many as 12 lactations. A high number of lactations could reflect that such sows are producing large litter sizes and thereby ensuring sufficient profit for farmers. Sows from extensive pig farming had a mean 2.62 years in production. During this time, they accumulated costs of 86,685 CZK. The higher costs of these sows relate to the longer periods that they remained in the herd. On the other hand, sows from intensive pig farming had a mean 1.73 years in production and embodied costs lower by 26,828 CZK and totaling 59,857 CZK. Sows culled later than at the seventh litter could be poor mothers, have problems with milkiness, produce unbalanced litters, and more frequently crush their piglets, and all these aspects negatively influence farm profitability (Čeřovský, 2002). The sows evaluated in this study that achieved higher numbers of litters also had higher numbers of stillborn piglets, lower numbers of live-born piglets, and lower numbers of weaned piglets. This could reflect more frequent crushing of piglets, poorer milkiness of sows, or their production of unbalanced litters. Sows should be culled from the breeding herd after a maximum of six lactations. Most often, sows are culled after their fourth farrowing (Dourmad et al., 1994; Koketsu et al., 1999). This was confirmed by this study only in one case. This statement is true for intensive pig farming, which aims to maximize the reproductive potential of sows already from their first litters. Such a breeding plan is economically advantageous for the farm. Serenius and Stalder (2004) have reported that higher numbers of piglets per litter have positive effect on the longevity and profitability of sows. It is apparent from this study that sows from intensive pig farming have higher numbers of piglets per year and are culled earlier. Sows from extensive pig farming, by contrast, have fewer piglets per litter and are culled later. It is also true, however, that lower numbers of piglets can mean those piglets born have higher birth weights, and Nevrkla et al. (2017) report that piglets with higher birth weights reach slaughter weight earlier. This could be a big advantage for farm profitability. Our results show that sows from the intensive pig farm achieved a mean lifetime profit advantage of 17,878 CZK over sows from the extensive pig farm. This higher profit is what matters decisively for the farms.

\section{CONCLUSION}

Sows from intensive farming had better reproductive performance and greater profitability than did sows from extensive farming, despite that their reproductive potential was maximized and they were culled earlier from the herd. This earlier culling under intensive versus extensive pig farming was possible because maximizing the animals' high reproductive potential brought earlier recovery of the costs of rearing and maintaining those animals in the breeding herd. This is important for all pig farms. Maximizing sows' reproductive potential can positively affect farm profitability without negatively impacting reproductive performance. Farm profitability is very important today, and, regardless of the farming system in use, it is important to have excellent knowledge of the biological principles of sows' reproductive potential and properly to use that knowledge to avoid negatively affecting sow health and reproductive performance. Particularly in the case of extensive pig farming, it is economically very important to practice good management to minimize pig losses.

\section{Acknowledgements}

This study was supported by the Ministry of Education, Youth and Sports of the Czech Republic (Project No. MSM 6046070901) and by the project (NAZV: QJ1510191).

\section{REFERENCES}

AASMUNDSTADT, T., OLSEN, D., SEHESTED, E. et al. 2014. The genetic relationships between conformation assessment of gilts and sow reproduction and longevity. Livestock science, 167: 33-40.

BABICZ, M., REJDUCH, B., KOUBSKA-SOBOCIŃSKA, A. et al. M. 2011. Analysis of sexual activity in gilts in terms of their reproductive value. Annals of Animal Science, 11(2): 241-250.

BEEK, J., DE JONG, E., VAN SOOM, A. et al. 2011. Ovarian cysts in sows: a multifactorial disorder with consequences on the reproductive performance. Vlaams Diergeneeskundig Tijdschrift, 80(3): 215-222.

BABOT, D., CHAVEZ, E. R. and NOGUERA, J. L. 2003. The effect of age at the first mating and herd size on the lifetime productivity of sows. Animal Research, 52(1): 49-64.

BEYGA, K. and REKIEL, A. 2010. The effect of the body condition of late pregnant sows on fat reserves at farrowing and weaning and on litter performance. Archiv Fur Tierzucht-Archives of Animal Breeding, 53(1): 50-64. 
BRZOBOHATÝ, L., STUPKA, R., ČÍTEK, J. et al. 2015. The effect of the backfat thickness loss on reproduction in lactating sows. Journal of Central European Agriculture, 16(2): 1-9.

ČEǨOVSKÝ, J. 2002. Higher piglet production per sow is a step in the right direction [in Czech: Vyšší produkce selat na prasnici je krok správným směrem]. Farmář, 8: 41-43.

DOURMAD, J. Y., ETIENNE, M., PRUNIER, A. et al. 1994. The effect of energy and protein-intake of sows on their longevity - a review. Livestock production science, 40(2): 87-97.

ENGBLOM, L., LUNDHEIM, N., SCHNEIDER, M. D. et al. 2009. Genetics of crossbred sow longevity. Animal, 3(6): 783-790.

HELLBRÜGGE, B., TÖLLE, K. H., BENNEWITZ, J. et al. 2008. Genetic aspects regarding piglet losses and the maternal behaviour of sows. Part 1. Genetic analysis of piglet mortality and fertility traits in pigs. Animal, 2(9): 1273-1280.

HOGE, M. D. and BATES, R. O. 2011. Developmental factors that influence sow longevity. Journal of Animal Science, 89(4): 1238-1245.

KNECHT, D. and DUZIŃSKI, K. 2014. The effect of parity and date of service on the reproductive performance of Polish large white x Polish landrace (PLW x PL) crossbred sows. Annals of Animal Science, 14(1): 69-79.

KOKETSU, Y., TAKAHASHI, H. and AKACHI, K. 1999. Longevity, lifetime pig production and productivity, and age at first conception in a cohort of gilts observed over six years on commercial farms. Journal of veterinary medical science, 61(9): 1001-1005.

MADEJ, A., LANG, A., BRANDT, Y. et al. 2005. Factors regulating ovarian function in pigs. Domestic animal endocrinology, 29(2): 347-361.

MILLIGAN, B. N., FRASER, D. and KRAMER, D. L. 2002. Within-litter birth weight variation in the domestic pig and its relation to pre-weaning survival, weight gain, and variation in weaning weights. Livestock Production Science, 76(1-2): 181-191.

NEVRKLA, P., VÁCLAVKOVÁ, E., HADAŠ Z. et al. 2017. Effect of Birth Weight of Piglets on Their Growth Ability, Carcass Traits and Meat Quality. Acta Universitatis Agriculturae et Silviculturae Mendelianae Brunensis, 65(1): 0119-0123.

NOGAJ, J., JARCZYK, A. and KOWALEWSKI, D. 2006. The effect of selected factors on litter and piglet weight at the age of 21 days. Animal Science Papers and Reports, 24(1): 93-101.

ROONSITTHICHAI, A. and TUMMARUK, P. 2014. Importance of back-fat thickness to reproductive performance in female pigs. Thai journal of veterinary medicine, 44(2): 171-178.

SERENIUS, T. and STALDER, K. J. 2004. Genetics of length of productive life and lifetime prolificacy in the Finnish Landrace and Large White pig populations. Journal of animal science, 82(11): 31113117.

ŠKORPUT, D., DUJMOVIĆ, Z., KAROLYI, D. et al. 2018. Variability of birth weight and growth of piglets in highly prolific sows. Journal of Central European Agriculture, 19(4): 823-828.

SOEDE, N. M., HOVING, L. L., VAN LEEUWEN, J. J. J. et al. 2013. The second litter syndrome in sows; causes, consequences and possibilities of prevention. In: Proceedings of the $9^{\text {th }}$ International Conference on Pig Reproduction. Satellite Symposium. Olsztyn, Poland, 9-12 June. Olsztyn: Satellite Symposium, pp. 28-34.

SZULC, K., SKRZYPCZAK, E., PANEK, A. et al. 2011. Analysis of reproduction and litter performance of the Zlotnicka Spotted breed and its different crossbreeds. Italian Journal of Animal Science, 10(4): 184-187.

IAEI. 2018. Cost of agricultural products [in Czech: Nákladovost zemědělských výrobků]. IAEI. [Online]. Available at: https://www.uzei.cz/nakladovost-zemedelskych-vyrobku/ [Accessed: 2018].

WÄHNER, M. and BRÜSSOW, K. P. 2009. Biological potential of fecundity of sows. Biotechnology in Animal Husbandry, 25(5-6): 523-533.

WILLIAMS, N. H., PATTERSON, J. and FOXCROFT, G. 2005. Non-negotiables in gilt development. Advances in Pork Production, 16: 281-289.

Contact information

Kamila Pokorná: pokornakamila@af.czu.cz 